\title{
PELATIHAN PEMBUATAN PROPOSAL RENCANA BISNIS (BUSINESS PLAN) BAGI SISWA MADRASAH TSANAWIYAH NURUL HIKMAH DAN SMP AL-IHSAN GUNA MENINGKATKAN KEMAMPUAN BERWIRAUSAHA
}

\author{
Hugo Aries Suprapto ${ }^{1}$, Muhammad Rusdi², Paryono ${ }^{3}$ \\ 1,2,3 UNIVERSITAS INDRAPRASTA PGRI JAKARTA \\ 1 bapak.aries@gmail.com \\ 2 m.rusdy@yahoo.com \\ 3 paryono.oetomo@yahoo.com
}

\begin{abstract}
ABSTRAK
Kegiatan ini bertujuan untuk memberikan pemahaman kepada siswa-siswi tentang pentingnya membuat proposal rencana bisnis untuk meningkatkan kemampuan berwirausaha. Target luaran kegiatan ini adalah diharapkan siswa - siswi lebih mudah dan mengerti dalam memahami penulisan proposal dengan menumbuhkan ide kreatif dan inovasi dan meningkatkan motivasi berwirausaha. Metode kegiatan yang dilakukan tim abdimas dengan dua tahapan, tahap [1]. Observasi langsung, yaitu: tim abdimas langsung datang ke lokasi, untuk memperoleh data. Hal ini dilakukan pada saat menjelang maupun pada saat kegiatan berlangsung Tahap; ke [2]. Demontrasi, yaitu: tim pengabdi mengajarkan secara langsung cara belajar membuat business plan kepada siswa-siswi Madrasah Tsanawiyah Nurul Hikmah dan siswa-siswi SMP Al-Ihsan. Pengajaran akan dilakukan 4 tatap muka agar siswasiswi SMP Nurul Hikmah dan SMP Al-Ihsan lebih memahami penulisan proposal bisnis yang akan diajarkan.
\end{abstract}

Kata Kunci : Proposal Rencana Bisnis dan Kemampuan Berwirausaha

\begin{abstract}
This activity aims to provide understanding to the students about the importance of making business plan proposal to improve entrepreneurship skills. The outcome target of this activity is expected the students - students easier and understand in understanding the writing of proposals by fostering creative ideas and innovation and improve entrepreneurship motivation. The method of activity performed by the team is abdimas with two stages, stage [1]. Direct observation, ie: team abdimas directly come to the location, to obtain data. This is done at the time of the Phase; 2nd]. Demonstration, namely: team of devotees teach directly how to learn to make business plan to students of Madrasah Tsanawiyah Nurul Hikmah and student of SMP Al-Ihsan. Teaching will be conducted 4 face to face so that the students of SMP Nurul Hikmah and SMP Al-Ihsan better understand the writing of business proposal that will be taught.
\end{abstract}

Keywords: Business Plan Proposal and Entrepreneurship Capability

\section{A. PENDAHULUAN}

Undang-Undang Republik Indonesia Nomor 20 tahun 2003 tentang Sistem Pendidikan Nasional menggariskan bahwa pembangunan di bidang pendidikan adalah upaya mengembangkan kemampuan dan membentuk watak serta peradaban bangsa yang bermartabat dalam rangka mencerdaskan kehidupan bangsa, bertujuan 
berkembangnya potensi peserta didik agar menjadi manusia beriman dan bertakwa terhadap Tuhan Yang Maha Esa, berakhlak mulia, sehat, berilmu, cakap, kreatif, mandiri dan menjadi warga negara demokratis serta bertanggung jawab (Depdiknas, UU No. 20 Tahun 2003 : pasal 13).

Taqiyudin (2010:102) menuliskan, pendidikan berwawasan kewirausahaan yaitu pendidikan yang menerapkan prinsip-prinsip dan metodologi ke arah pembentukan kecakapan hidup (life skill) pada peserta didiknya melalui kurikulum yang terintegrasi yang dikembangkan di sekolah. Dalam proses belajar mengajar, guru memiliki andil yang sangat besar terhadap pembelajaran di sekolah. Seperti yang dikemukakan oleh E. Mulyasa (2005:35) bahwa, guru sangat berperan dalam membantu perkembangan peserta didik untuk mewujudkan tujuan hidupnya secara optimal. Begitu pula dalam proses belajar mengajar kewirausahaan, guru memiliki peran strategis dalam menanamkan sikap kewirausahaan bagi siswa.

Dalam membangun satu bisnis baik itu bisnis rumahan, usaha sampingan maupun usaha kecil menengah anda tentunya membutuhkan modal baik untuk modal awal maupun modal pengembangan bisnis anda. Tak dapat di pungkiri bahwa modal merupakan faktor pendukung meskipun bukan yang paling utama namun modal bisa jadi kekuatan yang mampu mendongkrak bisnis anda agar lebih berkembang. Ketika anda ingin mendapatkan modal namun anda terkendala dengan peraturan dari bank atau anda takut untuk meminjam dari kredit bank atau pinjaman lain maka salah satu cara yang dapat anda lakukan dan terbukti berhasil adalah dengan cara menjalin kerjasama dengan investor. Dalam menjalin kerjasama tersebut maka anda perlu mempersiapkan proposal usaha untuk mencari modal dengan cara investasi.

Kendala paling umum adalah ketidak tahuan bagaimana cara membuat proposal yang baik dan benar, kendala ini bukan hanya terjadi kepada mereka yang kurang beruntung dalam mendapatkan pendidikan tinggi tapi mereka yang notebene telah mendapatkan pengalaman di bangku sekolah mengaku sulit untuk membuat proposal usaha. Sekolah sebagai suatu institusi atau lembaga pendidikan idealnya harus mampu melakukan proses edukasi, sosialisasi, dan transformasi. Dengan kata lain, sekolah yang bermutu adalah sekolah yang mampu berperan sebagai proses edukasi (proses pendidikan yang menekankan pada kegiatan mendidik dan mengajar), proses sosialisasi (proses bermasyarakat terutama bagi anak didik), dan wadah proses transformasi (proses perubahan tingkah laku ke arah yang lebih baik/ lebih maju). 
Salah satu bagian kunci dalam pendidikan anak atau proses pembelajaran pendidikan di sekolah membentuk karakter atau sikap mental positif siswa, karena terbentuknya mental positif siswa akan mampu menghantarkan setiap individu meraih kesuksesan (Hendrojogi, 2000:14). Proses pembelajaran melalui interaksi guru dan siswa, siswa dan siswa, dan siswa dengan guru, secara tidak langsung menyangkut berbagai komponen lain yang saling terkait menjadi satu sistem yang utuh. Perolehan hasil belajar sangat ditentukan oleh baik tidaknya kegiatan dan pembelajaran selama program pendidikan dilaksanankan di kelas yang pada kenyataannya tidak pernah lepas dari masalah.

Proses belajar mengajar kewirausahaan masih terfokus pada guru dan kurang terfokus pada siswa. Hal ini mengakibatkan kegiatan belajar mengajar (KBM) lebih menekankan pada pengajaran daripada pembelajaran. Peran serta siswa belum menyeluruh sehingga menyebabkan diskriminasi dalam kegiatan pembelajaran. Siswa yang aktif dalam KBM cenderung lebih aktif dalam bertanya dan menggali informasi dari guru maupun sumber belajar yang lain sehingga cenderung memiliki pencapaian kompetensi belajar yang lebih tinggi. suatu terobasan yang data membantu dalam bidang kewirausahaan.dan pembelajaran yang mampu melibatkan peran serta siswa secara menyeluruh sehingga kegiatan belajar mengajar tidak hanya didominasi oleh siswa-siswa tertentu saja. Selain itu, melalui pemilihan metode pembelajaran tersebut diharapkan sumber informasi yang diterima siswa tidak hanya dari guru melainkan juga dapat meningkatkan peran serta dan keaktifan siswa dalam mempraktekan kewirausahaan itu sendiri.

\section{B. LANDASAN TEORI}

\section{Meningkatkan Kemampuan Berwirausaha}

Sukses sebagai wirausaha tergantung pada kemampuan anda mengambil keputusan-keputusan yang meningkatkan kemampuan bisnis anda yang akan datang. Kemampuan diperoleh dari pengalaman harus membuat keputusan-keputusan penting. (Kewirausahaan. Geoffery G. Meredith. 1995:56). Kewirausahaan merupakan mata pelajaran yang dapat diajarkan di sekolah-sekolah dan telah bertumbuh sangat pesat.

Transformasi pengetahuan kewirausahaan telah berkembang pada akhir-akhir ini. Demikian pula di negara kita, pengetahuan kewirausahaan diajarkan di sekolah dasar, sekolah menengah, perguruan tinggi dan di berbagai kursus bisnis. Jadi 
kesimpulannya kewirausahaan itu dapat diajrkan. Berikanlah para siswa penanaman sikap-sikap untuk membuka bisnis kemudian kita akan membuat mereka menjadi seorang wirausaha yang berbakat. (Buchari Alma, 2014:6).

\section{Proposal Business Plan}

Bisnis adalah sesuatu yang menyenangkan. Bisnis merupakan permainan yang segar dan menumbuhkan rasa percaya. Dunia bisnis, apapun jenis usahanya, perlu keterbukaan. Mengapa? Karena kita ingin menciptakan unit bisnis yang memberikan peluang kepada setiap orang untuk ikut berjuang mencari uang. Denag keterbukaa, semua ikut berpikir dan bertindak seperti pemilik, bukan sekedar sebagai orang yang digaji. Itupun model usaha yang mungkin dapat diterapkan saat ini, ketika perekonomian Indonesia tidak mengalami perbaikan yang signifikan dan dihadapkan pada persaingan global yang sangat masif. (Moh. Alifuddin dan Mashur Razak, 2015:46).

Bussiness plan berfungsi untuk merancang stategi dan rencana awal bisnis. Sebuah bisnis akan sulit berkembang apabila dijalankan tanpa rencana ataupun rancangan bisnis. Untuk itu sangatlah penting bagi seorang wira usaha untuk menyusun sebuah rencana bisnis agar bisnis yang ditekuni lebih terarah dan terorientasi dengan benar dan dapat mencapai kesuksesan. Sebuah perencanaan usaha/bisnis, normalnya mengandung serangkaian elemen-elemen standar. Format dan bentuk perencanaan sangat bervariasi, tetapi biasanya sebuah perencanaan bisnis akan berisi komponenkomponen seperti deskripsi perusahaan, produk atau jasa yang dihasilkan perusahaan, pasarnya, prediksi atau ramalan-ramalan ke depan, team manajemennya dan analisis finansial/keuangannya. Business Plan merupakan suatu dokumen yang menyatakan keyakinan akan kemampuan sebuah bisnis untuk menjual barang atau jasa dengan menghasilkan keuntungan yang memuaskan dan menarik bagi penyandang dana. (Bygrave 1994: 114)

Jadi business plan adalah dokumen tertulis yang disiapkan oleh wirausaha yang menggambarkan semua unsur-unsur yang relevan baik internal maupun eksternal mengenai perusahaan untuk memulai sewaktu usaha. Isinya sering merupakan perencanaan terpadu menyangkut pemasaran, permodalan, manufaktur dan sumber daya manusia. (Hisrich-Peters, 1995:113) dalam buku kewirausahaan (Buchari Alma, 2014:219). 


\section{METODE PELAKSANAAN}

Kegiatan pelatihan pembuatan business plan untuk meningkatkan kemampuan berwirausaha ini, dilaksanakan di sekolah madrasah Tsanawiyah Nurul Hikmah dan di sekolah SMP Al-Ihsan Kota Bekasi Jawa Barat. Kegiatan abdimas ini dilakukan dengan metode diskusi, tanya jawab dan simulasi hasil sosialisasi oleh siswa.

\section{Tahapan Pelaksanaan}

Kegiatan pengabdian dilaksanakan pada bulan Januari 2018 s/d April 2018 dengan tahapan pelaksanaan kegiatan adalah sebagai berikut:

a. Mengadakan observasi langsung ke Madrasah Tsanawiyah Nurul Hikmah dan SMP Al-Ihsan Kota Bekasi untuk melihat proses pembelajaran di kelas dan kegiatan yang dilakukan siswa, baik di dalam kelas maupun di luar kelas sebagai penunjang data.

b. Mengenalkan kepada siswa-siswi tentang pentingnya konsep berwirausaha dengan pembuatan proposal business plan.

c. Melakukan sosialisasi kepada siswa-siswi untuk terbiasa latihan dalam membuat proposal untuk menunjang keberhasilan bisnis.

d. Memberikan kesempatan kepada siswa-siswi untuk mengimplementasikan hasil pembuatan proposal business plan.

\section{Pelaksanaan Kegiatan}

Kegiatan sosialisasi dilakukan atas dasar perizinan dari pihak sekolah, yaitu: SekolahMadrasah Tsanawiyah Nurul Hikmah dan SMP AL-Ihsan Kota Bekasi. Kegiatan sosialisasi ini diawali dengan observasi lapangan untuk mengetahui kondisi sekolah dan proses pembelajaran di kelas. Hal ini dimaksudkan agar pelaksanaan kegiatan sosialisasi dapat disesuaikan dengan kondisi belajar, guru, jadwal, dan fasilitas yang ada di sekolah.

Kegiatan berikutnya adalah melakukan bimbingan pelatihan sosialisasi pembuatan proposal business plan dengan menggunakan in-focus, agar siswa-siswi dapat melihat, memahami penjelasan yang terkandung di dalam business plan. Kegiatan dilaksanakan di dalam kelas. Semua siswa belum tahu mengenai gambaran business plan, pengertian, bahkan manfaat pembuatan proposal digunakan untuk apa. Masalahmasalah yang dihadapi oleh siswa-siswi beraneka ragam, mulai dari langkah pertama berkaitan dengan ide judul pembuatan proposal, kurang paham dalam membuat latar belakang masalah, elemen-elemen apa saja yang ada di business plan. 
Berdasarkan hasil pengenalan dan sosialisasi yang telah dilaksanakan kepada siswa-siswi di sekolah, maka dilakukan simulasi pembelajaran oleh tim abdimas dengan cara diberikan materi business plan (mulai dari pengertian, tujuan dan manfaat business plan) dan contoh proposal business plan yang sudah ada. Hasil simulasi terhadap peserta didik menunjukkan antusiasme pserta didik yang lebih tinggi terhadap materi ajar, karena yang disampaikan oleh tim abdimas lebih efektif dan efisien.

\section{HASIL DAN PEMBAHASAN}

\section{Hasil}

Kegiatan pelatihan pembuatan proposal business plan untuk meningkatkan kemampuan berwirausaha siswa telah dilaksanakan di Madrasah Tsanawiyah Nurl Hikmah dan SMP AL-Ihsan Kota Bekasi Jawa Barat, yang dilakukan oleh tim abdimas dari Universitas Indraprasta PGRI Jakarta yang beranggotakan 3 (tiga) orang. Kegiatan dilaksanakan terhadap siswa-siswi di ruang kelas. Kegiatan ini diawali dengan observasi dua mitra tersebuat pada bulan Januari 2018 untuk mengumpulkan informasi, menganalisa masalah dan mengidentifikasikan segala yang berkaitan dengan siswa. Di bulan Februari, tim abdimas melakukan pembuatan materi untuk memudahkan sosialisasi pembelajaran. Pada bulan Maret melaksanakan demonstrasi kegiatan pembelajaran.

Berdasarkan sosialisasi kegiatan pembelajaran ini, diperoleh hasil sebagai berikut: [1]. Siswa-siswi antusias mencoba untuk menjadi seorang wirausaha dan pelaksanaan harus memiliki business plan yang terarah dan baik ; [2]. Siswa-siswi lebih bersemangat dalam mencapai masa depannya.

\section{Pembahasan}

Berdasarkan hasil dari kegiatan abdimas ini, siswa-siswi Madrasah Tsanawiyah Hurul Hikmah dan SMP AL-Ihsan Kota Bekasi merasa terbantu, termotivasi dan memiliki wawasan baru dan memiliki kecakapan keterampilan dalam meningkatkan minat berwirausaha. Pembenahan juga harus dilakukan pada kurikulum pendidikan formal, artinya kurikulum pendidikan di setiap satuan pendidikan harus memasukkan unsur pendidikan wirausaha pada siswa dengan baik (Buchari Alma, 2009:107). Beberapa alternatif yang dapat dilakukan dalam mengembakan kurikulum wirausaha antara lain: mengembangkan satu bidang studi tentang wirausaha. Hal ini dapat dilakukan dengan cara tidak terlalu banyak merubah sistem pengajaran yang telah 
berjalan, disajikan mengikuti pola pengajaran bidang studi yang ada, isi dan ruang lingkup kajian (materi pembelajaran) disusun sedemikian rupa sesuai dengan jenjang pendidikan peserta didik.

\section{E. KESIMPULAN}

Berdasarkan hasil pelaksanaan pengabdian pada masyarakat yang telah dilaksanakan di sekolah Madrasah Tsanawiyah dan SMP AL-Ihsan Kota Bekasi Jawa Barat, maka dapat disimpulkan hal-hal sebagai berikut:

1. Kegiatan pengabdian masyarakat ini dapat memberikan manfaat langsung kepada siswa dalam meningkatkan pengetahuan, keterampilan dalam berwirausaha.

2. Penggunaan media latihan pembuatan proposal business plan ini, harus lebih dibiasakan dan terarah, lebih kreatif dan menarik, agar siswa lebih memahami materi yang disampaikan.

3. Kegiatan abdimas ini membutuhkan dukungan semua pihak, termasuk sekolah, dan dinas pendidikan setempat untuk dapat menyediakan dan memfasilitasi pelatihanpelatihan dan bahan ajar serta media audio visual lainnya untuk meningkatkan pengetahuan bagi para peserta didik.

\section{F. DAFTAR PUSTAKA}

Buchari Alma. [2009]. Kewirausahaan. Bandung: Alfabeta.

Buchari Alma. [2014]. Kewirausahaan. Cetakan ke.20. Bandung: Alfabeta.

Bygrave, William D. [1994]. The portable MBA in Entrepreurship. John Willey \& Sons, Inc. New York.

E.Mulyasa. [2005]. Menjadi Guru Professional. Bandung : Remaja Rosdakarya.

Geoffrey G, M. [1995]. Kewirausahaan. Jakarta: C.V. Taruna Grafica.

Hendrojogi. [2000]. Koperasi dan Azas-Azas, Teori dan Praktek. Jakarta : Rajawali Press Instruksi.

Hisrich, Robert. D., Peters M. P. [1995]. Entrepreusrship. Irwin. Chicago.

Iis Dewi, Halimatusha, Fibria. Penggunaan Media Audio, Visual, Dan Audiovisual Dalam Meningkatkan Pembelajaran Kepada Guru. Jurnal PKM: Pengabdian Kepada Masyarakat. Vol. 01 No. 01, Januari 2018. p-ISSN 2614 
Moh. Alifuddin dan Mashur Razak. [2015]. Kewirausahaan: Strategi Membangun Kerajaan Bisnis. Jakarta: Magna Script Publishing.

Taqiyuddin. [2010]. Laedershif \& Entrepreneurship. Cirebon: IDEA Publishing. 